\title{
Determinants of Profitability: Evidence from Industrial Companies Listed on Muscat Securities Market
}

\author{
Mohamed Khaled Al-Jafari ${ }^{1} \&$ Hazem Al Samman ${ }^{2}$ \\ ${ }^{1}$ Department of Accounting and Finance, College of Business Administration, Prince Mohammad Bin Fahd \\ University, Al Khobar, Kingdom of Saudi Arabia \\ ${ }^{2}$ Department of Accounting and Finance, College of Commerce and Business, Dhofar University, Dhofar, \\ Sultanate of Oman \\ Correspondence: Mohamed Khaled Al-Jafari, College of Business Administration, Department of Accounting \\ and Finance, Prince Mohammad Bin Fahd University, P. O. Box 1664, Al Khobar 31952, Kingdom of Saudi \\ Arabia. Tel: 966-530-052-740. E-mail: aljafarimohamedkhaled@yahoo.com
}

Received: June 1, 2015 Accepted: June 19, 2015 Online Published: August 14, 2015

doi:10.5539/res.v7n11p303 URL: http://dx.doi.org/10.5539/res.v7n11p303

\begin{abstract}
This study investigates the determinants of profitability for industrial firms in Oman. Therefore, a sample of 17 industrial companies listed on Muscat securities market covering the period from 2006 till 2013 is utilized. Results from the panel ordinary least squares model reveal a positive and statistical significant relationship between profitability, the firm size, growth, fixed assets and working capital. On the other hand, the average tax rate and the financial leverage variables show a negative relationship with profitability. However, this relationship is significant only for the financial leverage variable. The study concludes that large growing firms with efficiently managed assets improve revenue and ultimately enhance profitability.
\end{abstract}

Keywords: profitability, working capital, fixed assets, size, growth, financial leverage, average tax rate, industrial companies, Oman, panel ordinary least squares

\section{Introduction}

The magic word "Profitability" refers to earnings of companies that are generated from revenues and after deducting all expenses incurred during a given period. It is considered one of the most important goal that management of every company strives to achieve and without it companies will ceased. Ultimately, the goal of the firm is to maximize the wealth of its shareholders by increasing the value of their stocks. However, literature in finance provided evidence of a strong relationship between earnings and stock values. Accordingly, if earnings announcements come as expected or better, stock prices will increase. On the other hand, if earnings announcements fell short of expectations, the stock prices will decline.

Due the importance of this subject, a large volume in the literature investigated factors that influence profitability of the firms. For instance, Hurdle (1974), McDonald (1999), Stierwald (2010), Yazdnafar (2013) among others, examined the effect of lagged profits on current profits. On the other hand, the impact of the size of the firm on profitability was tested by Bain (1951), Hall and Weiss (1967), Keith (1998), Feeny (2000), Nunes, Serrasqueiro, and Sequeira (2009), Stierwald (2010), Yazdnafar (2013), Pratheepan (2014), Zaid, Ibrahim, and Zulqernain (2014), among others. In addition, the influence of working capital management on profitability was explored by Grinyer and McKiernan (1991), Goddard, Tavakoli, and Wilson (2005), Chowdhury and Amin (2007), Dong and Su (2010), Alipour (2011), Charumathi (2012), Mistry (2012), among others. The relationship between age of the firm and profitability was also investigated by Geroski and Jacquemin (1988), Keith (1998), Bhayani (2010), Malik (2011), Agiomirgianakis, Magoutas, and Sfakianakis (2013), among others. Similarly, the impact of using debt on the profitability was investigated also by Hurdle (1974), Burja (2011), Eriotis, Frangouli, and Ventoura-Neokosonides (2011), Mistry (2012), Innocent, Mary, and Matthew (2013), Boadi, Antwi, and Lartey (2013), among others.

Building on previous studies, the objective of this paper is to investigate factors that influencing the profitability of industrial companies in Oman. These factors to include the average tax rate, the size of the firm, the growth rate, the fixed assets of the company, the financial leverage and working capital management of the company. It 
is worth mentioning, there is a scarcity in the literature investigating the determinants of profitability for industrial firms in Oman. Therefore, determining those factors will constitute great benefits to stakeholders of these firms specifically, creditors, investors, management and shareholders.

This study is organized into 5 sections as follows: Section 2 displays briefly previous studies. On the other hand, section 3 explains the source of data, the hypotheses under investigation and the research model. Results of the tested hypotheses are included in section 4 . Finally, section 5 concludes the study.

\section{Literature Review}

Literatures related to the determinants of profitability for different types of industries are abundant. However, most of them have produced a mixed results. Therefore in this section, we will provide latest updated findings related to this issue. For instance, Grinyer and McKiernan (1991) investigated the determinants of profitability for 45 UK electrical companies using multiple regression analysis. The results show that market share, capital intensity, growth of sales, working capital and decentralization play a significant role in explaining corporate profitability. On the other hand, Bennenbroek and Harris (1995) examined the determinants of profitability for New Zealand manufacturing industry covering the year 1986-1987. Their findings reveal that market power and market efficiency are important factors that influence profitability. In contrast, Keith (1998) used a sample of 38 small manufacturing firms in the Tayside Region of Scotland. He found that the characteristics of the company include size, age, location and industry group have a limited value in explaining profitability. Subsequently, McDonald (1999) tested the determinants of profitability for the Australian manufacturing companies. The results show that a lagged profitability and industry concentration are important in determining profitability.

Similarly, Feeny (2000) utilized the simple regression techniques on 180,738 tax entities from the Australian Tax Office to find out the determinants of profitability. The findings show a strong evidence of a positive association between capital intensity, size and profitability. On the other hand, Goddard, Tavakoli, and Wilson (2005) examined the determinants of profitability for manufacturing and service firms in Belgium, France, Italy and the UK. The results provide evidence of negative relationship between size, the gearing ratio and profitability. In contrast, the results show a positive relationship between market share and profitability and that higher liquidity leads also to higher profitability. In addition, Amir Shah and Sana (2006) tested the profitability of the oil and gas sector in Pakistan. Their findings reveal a negative relationship between profitability, age of inventory, average collection period and sales growth. The number of days of accounts payable found to have a positive relationship with profitability. Similarly, Chowdhury and Amin (2007) investigated the profitability of pharmaceutical companies listed in Dhaka stock exchange. The results provided evidence of working capital policy impact on profitability as measured by return on assets (ROA).

Moving to India, Bhayani (2010) examined factors that influence profitability for cement firms covering the period from 2001 till 2008. He concluded that liquidity, age of the firm, operating ratio, interest rate and inflation are important determinants of profitability for the Indian cement industry. In addition, Nunes, Serrasqueiro and Sequeira (2009) examined the profitability of the Portuguese service industry. They found a positive relationship between size, growth and profitability. Moreover, they concluded that higher liquidity will not decrease profitability. On the other hand, lower level of debt and lower level of fixed assets are more profitable for Portuguese service companies. Similar results were obtained by Asimakopoulos, Samitas, and Papadogonas (2009). They tested profitability for non-financial firms listed on Athens stock exchange. Their findings reveal that size, sales growth and investment have a positive effect on profitability. In contrast, leverage and working capital showed a negative effect on profitability. At the same time, Ha-Brookshire (2009) examined the relationship between size, firm entrepreneurship and performance for US non-manufacturing companies. The results suggest that the size of the firm affect both entrepreneurship and performance. Moving back again to Australia, Stierwald (2010) utilized the random and fixed effect regression on 961 large Australia firms to investigate the determinants of profitability. The results reveal a large positive impact of lagged profit, productivity level and size on firm's profitability. On the other hand, Dong and Su (2010) investigated the relationship between working capital management and profitability for firms listed on Vietnam stock market. The findings show a strong negative relationship between operating profit and the cash conversion cycle. In addition, Ito and Fukao (2010) studied the determinants of Japanese manufacturing affiliates in China and other regions for the period 1989 till 2002. The results reveal that promoting local procurements and local sales have a positive impact on profitability. Therefore, firms that have higher local sales ratio were more profitable than firms with low sales ratio. They concluded that Japanese affiliates in China should promote expansion of local sales.

Subsequently, Burja (2011) examined factors that influence profitability for the Romanian chemical industry. 
The results provided evidence of a strong positive relationship between efficiency of inventory, debt level, financial leverage, efficiency of capitals and profitability. On the other hand, Eriotis, Frangouli, and Ventoura-Neokosonides (2011) investigated the relationship between debt to equity ratio and profitability. They concluded that financing investments using retained profits were more profitable than using borrowed funds. In addition, the study found a negative and statistical significant impact of the concentration ratio on profitability. Furthermore, Malik (2011) tested the profitability of 35 life and non-life insurance companies in Pakistan. The findings reveal the existence of no relationship between profitability and age of the firm. In contrast, there were a positive and significant relationship between size of the company, volume of capital and profitability. In addition, Alipour (2011) employed the multiple regression technique and the Pearson's correlation test on 1063 companies accepted in Tehran stock exchange. The results show a significant relationship between working capital management and profitability. Similarly, Charumathi (2012) investigated the determinants of profitability for the Indian life insurance companies. The results provided evidence of a positive and significant relationship between size, liquidity, and profitability. However, leverage, premium growth, and equity capital found to have a negative and significant impact on profitability. Likewise, Mistry (2012) examined the Indian automotive industry for five years period. The findings reveal a positive and significant relationship, in most years, between size, debt to equity ratio, and inventory turnover ratio. Liquidity of the firm found to have a negative and significant relationship with profitability.

Later, Innocent, Mary, and Matthew (2013) tested the profitability of the pharmaceutical industry in Nigeria covering 11 years from 2001 till 2011. They provided evidence of negative and insignificant relation between profitability and each of debt turnover ratio, creditor's velocity, and total assets turnover ratio. Inventory turnover ratio also found to have negative but significant relation with profitability. On the other hand, Boadi, Antwi, and Lartey (2013) examined the determinants of profitability for the insurance companies in Ghana. Their results reveal a positive and significant relationship between leverage, liquidity and profitability. Furthermore, Agiomirgianakis, Magoutas, and Sfakianakis (2013) investigated factors that influence profitability for the tourism industry in Greece. They provided evidence that age, size, and low cost access to bank financing have a positive and significant impact on profitability. Similarly, Yazdnafar (2013) used seemingly unrelated regression on 12,530 non-financial micro firms operating in four industrial sectors in Sweden to measure the determinants of profitability as well as industry affiliation. The results reveal that size, lagged profitability, growth, and productivity have a positive influence on profitability. In addition, Elsiefy (2013) tested the determinants of profitability of commercial banks in Qatar. The study provided evidence of a strong relationship between liquidity and profitability for Islamic banks.

A more recent study by Al-Jafari and Alchami (2014) investigated the determinants of profitability of Syrian banks utilizing the generalized method of moments (GMM) technique. Their results reveal that liquidity ratio, credit risk, bank size, and management efficiency affect significantly the profitability of Syrian banks. Similarly, Pratheepan (2014) tested the determinants of profitability for 55 Sri Lankan manufacturing companies using static panel models. The results show that size has a significant positive relationship with profitability. Accordingly, tangibility found to have an inverse statistical relationship with profitability. On the other hand, leverage and liquidity found to have insignificant impact on profitability. Furthermore, Bashar and Islam (2014) examined the profitability of the pharmaceutical companies in Bangladesh. They conclude that managing inventory efficiently has a positive and significant effect on profitability. Moreover, reducing accounts payable should improve profitability of the firms. Likewise, Zaid, Ibrahim and Zulqernain (2014) investigated the determinants of profitability for the construction companies in Malaysia. They found that liquidity and size have a significant and positive relationship with profitability. On other hand, capital structure of the firm found to have negative and insignificant relationship with profitability.

\section{Data, Tested Hypotheses and Research Model}

\subsection{Data Description}

This study utilizes secondary data collected from annual reports of industrial firms listed on the website of Muscat securities market (www.msm.gov.om). The data includes the entire industrial firms listed on Muscat securities market, totaling 17 industrial companies and covering the period from 2006 till 2013.

The study employed the most important factors that influence firms' profitability and that are commonly utilized in the previous literature. The variables and their measurements used in this study are listed in Table 1. 
Table 1. Variables and measurements

\begin{tabular}{ll}
\hline Variable & Measurement \\
\hline Profit margin & Net income to sales \\
Return on assets & Net income to total assets \\
Average tax rate & Tax expense to earnings before tax \\
Size & Natural logarithm of sales \\
Growth & Assets value at year $\mathrm{t}$ to assets value at year t-1 \\
Fixed assets ratio & Fixed assets to total assets \\
Financial leverage & Total liabilities to market value of equity \\
Working capital & Current ratio, as current assets to current liabilities \\
\hline
\end{tabular}

\subsection{The Tested Hypotheses}

This study tests the following six null hypotheses:

$\mathbf{H}_{\mathbf{0 1}}$ : There is no statistical significant relationship between average tax rate and profitability of industrial firms in Oman.

$\mathbf{H}_{\mathbf{0 2}}$ : There is no statistical significant relationship between firm's size and profitability of industrial firms in Oman.

$\mathbf{H}_{\mathbf{0 3}}$ : There is no statistical significant relationship between firm's growth and profitability of industrial firms in Oman

$\mathbf{H}_{\mathbf{0 4}}$ :. There is no statistical significant relationship between fixed assets ratio and profitability of industrial firms in Oman.

$\mathbf{H}_{\mathbf{0 5}}$ : There is no statistical significant relationship between financial leverage and profitability of industrial firms in Oman.

$\mathbf{H}_{\mathbf{0 6}}$ : There is no statistical significant relationship between working capital and profitability of industrial firms in Oman.

\subsection{Model Specifications}

We utilize the panel ordinary least squares model as in equation 1 to examine the effect of the independent variables on the dependent variable of profitability of industrial firms in Oman, and to test the above six null hypotheses:

$$
\text { Profitabilty }_{i, t}=\beta_{0}+\beta_{1} \text { Tax }_{i, t}+\beta_{2} \text { Size }_{i, t}+\beta_{3} G R_{i, t}+\beta_{4} F A_{i, t}+\beta_{5} F L_{i, t}+\beta_{6} W C_{i, t}+\varepsilon_{t}
$$

Where:

Profitability: Measured by profit margin (PM) and return on assets (ROA)

Tax: Average tax rate

Size: Firm's size

GR: Firm's growth

FA: Fixed assets ratio

FL: Financial leverage

WC: Working capital

$\mathrm{i}, \mathrm{t}=$ for firm $\mathrm{i}$ in period $\mathrm{t}$ 


\section{Analysis of the Empirical Results}

In this section, we will display and discuss the descriptive statistics. In addition, we will analyze the correlation between variables and testing for multicollinearity. Finally, we will examine the results of the panel ordinary least squares in light of the hypotheses under investigation.

\subsection{Descriptive Statistics}

Table 2 shows that there is a high variations in the current ratio of industrial firms in Oman which measures the firm's ability to pay short-term obligations and efficiency of a company's operating cycle. Similarly, we can notice from the table that there is significant variations in the financial leverage where the standard deviation value is 0.78 . This may indicate that industrial companies in Oman have taken more risk. Therefore, it could result in a higher required rate of returns and ultimately impacting profitability and valuation of these firms.

Table 2. Descriptive statistics of variables

\begin{tabular}{lllllllll}
\hline & & & & & FIXED \\
& PM & ROA & TAXRATE & SIZE & GROWTH & ASSET & LMVE & CR \\
\hline Mean & 0.149809 & 0.099541 & 0.094416 & 15.94931 & 1.110686 & 0.479137 & 0.570574 & 2.673278 \\
Median & 0.102298 & 0.101870 & 0.114431 & 16.40600 & 1.082000 & 0.452787 & 0.311794 & 1.991743 \\
Maximum & 0.608196 & 0.266479 & 0.364198 & 19.83600 & 1.930000 & 0.842411 & 5.182441 & 11.69629 \\
Minimum & -0.101700 & -0.058800 & -0.227300 & 9.386000 & 0.001000 & 0.115066 & $4.62 \mathrm{E}-05$ & 0.508881 \\
Std. Dev. & 0.131160 & 0.060711 & 0.076650 & 2.519912 & 0.207716 & 0.210996 & 0.784382 & 2.183106 \\
Skewness & 0.989084 & 0.068442 & -0.624600 & -1.115400 & -0.384900 & -0.001100 & 3.232298 & 2.226810 \\
Kurtosis & 3.529596 & 2.940545 & 6.880998 & 3.652476 & 10.40241 & 1.769753 & 16.75270 & 8.668322 \\
Jarque-Bera & 21.14285 & 0.112289 & 83.80660 & 27.23438 & 279.2502 & 7.630619 & 1164.261 & 261.9882 \\
Probability & 0.000026 & 0.945403 & 0.000000 & 0.000001 & 0.000000 & 0.022031 & 0.000000 & 0.000000 \\
Sum & 18.12693 & 12.04445 & 11.42434 & 1929.867 & 134.3930 & 57.97557 & 69.03940 & 323.4666 \\
Sum Sq. Dev. & 2.064357 & 0.442297 & 0.705018 & 761.9949 & 5.177508 & 5.342337 & 73.83068 & 571.9142 \\
Observations & 121 & 121 & 121 & 121 & 121 & 121 & 121 & 121 \\
\hline
\end{tabular}

Furthermore, the table above indicates that there is high variation in net profit margin and return on assets. This result is consistent with high variation in financial leverage variable because higher degree of financial leverage will lead to more volatility in earnings.

The mean of fixed assets variable is 0.479 which reflect firms' investments in fixed assets. This is very important for industrial companies where large fixed assets investment is required in order to generate revenue and income. However, there is big difference between the maximum fixed assets value of 0.84 and the minimum value of 0.11 which may indicate a potential problem in capital budgeting decision that could affect ultimately the firms' profitability. Low values indicate that firms probably invested in areas that do not increase their revenue and income. On the other hand, high value may indicate that firms could have an excess fixed assets capacity that can be associated with low efficiency on part of the management. Therefore, high variation in this variable is also consistent with high variations in net profit margin and return on assets.

\subsection{Correlation between Variables}

Table 3 shows that there are a positive and significant relationship between net profit margin and both of fixed assets ratio and current ratio. Contrarily, there is a negative and significant relationship between net profit margin and financial leverage. In addition, we can observe that there is no significant relationship between net profit margin and each of the tax rate, size and growth variables. 
Table 3. Correlation between variables

\begin{tabular}{|c|c|c|c|c|c|c|c|c|}
\hline & & & TAX & & GRO- & FIXED & & \\
\hline & PM & ROA & RATE & SIZE & WTH & ASSET & LMVE & $\mathrm{CR}$ \\
\hline PM & 1.0000 & & & & & & & \\
\hline $\mathrm{ROA}$ & $0.7453 * * *$ & 1.0000 & & & & & & \\
\hline TAXRATE & -0.1231 & -0.0183 & 1.0000 & & & & & \\
\hline SIZE & 0.0620 & $0.1513^{*}$ & -0.0411 & 1.0000 & & & & \\
\hline GROWTH & 0.1295 & 0.1452 & -0.0026 & 0.1435 & 1.0000 & & & \\
\hline FIXEDASSET & $0.4955 * * *$ & 0.0630 & $-0.1855 * *$ & -0.1333 & -0.0292 & 1.0000 & & \\
\hline LMVE & $-0.3545^{* * *}$ & $-0.2547 * * *$ & -0.0581 & $0.2796 * * *$ & $0.1942 * *$ & $-0.2867 * * *$ & 1.0000 & \\
\hline $\mathrm{CR}$ & $0.2780 * * *$ & $0.3156 * * *$ & 0.0461 & $-0.2458 * * *$ & -0.0157 & -0.1000 & $-0.2540 * * *$ & 1.0000 \\
\hline
\end{tabular}

Note. $* * *, * *$ and $*$ denote significance at $1 \%, 5 \%$, and $10 \%$ levels respectively.

Furthermore, Table 3 shows that there is a positive and significant relationship between net profit margin and both of fixed assets variable and current ratio variable. On the contrary, there is a negative and significant relationship between net profit margin and financial leverage. Similarly, we can notice that there is no significant relationship between net profit margin and each of the tax rate, size and growth variables.

The table also indicates that there is a significant relationship between return on assets and each of the size and current ratio variables. Yet, there is negative and significant relationship between return on assets and financial leverage. Likewise, it is clear from the results that there is no significant relationship between return on assets and each of the tax rate, growth and fixed assets variables.

\subsection{The Analysis of Multicollinearity}

It is imperative to check for multicollinearity between the independent variables before we utilize the regression techniques. In general, there are two recognized tests that can detect multicollinearity. These tests are: the tolerance test and the variance inflation factor test (VIF). According to Menard (1955), a tolerance value of less than 0.1 constitutes a certain and serious collinearity problem.

Table 4. Collinearity statistics: Tolerance test and variance inflation factor (VIF)

\begin{tabular}{lll}
\hline Independent variable & Tolerance & VIF \\
\hline TAXRATE & 0.944 & 1.059 \\
Size & 0.870 & 1.149 \\
Growth & 0.948 & 1.055 \\
FIXEDASSET & 0.832 & 1.202 \\
LMVE & 0.770 & 1.299 \\
CR & 0.860 & 1.163 \\
\hline
\end{tabular}

On the other hand, Myers (1990) indicated that VIF value of greater than 10 must call for a concern. Accordingly, Table 4 shows that none of the tolerance level is below 0.1 and the VIF values are well below 10 . Therefore, multicollinearity is not a problematic issue or concern for this study.

\subsection{Results of the Panel Ordinary Least Squares}

According to results in Table 5, tax rate variable does not have significant effect on both profitability measures, the net profit margin and the return on assets. Therefore, we cannot reject the first hypothesis, and conclude that there is no statistical significant relationship between the average tax rate and profitability of industrial firms in Oman.

On the other hand, results in the same table also show that the size variable has a positive and significant effect on both net profit margin and return on assets. Therefore, we can reject the second hypothesis and conclude that 
there is statistical significant relationship between the firm size and profitability of industrial firms in Oman.

Similarly, Table 5 shows that the growth variable has a positive effect on the net profit margin and the return on assets at $5 \%$ and $10 \%$ significant level respectively. Therefore, we reject the third hypothesis and conclude that there is statistical significant relationship between the firm growth and profitability of industrial firms in Oman.

As for the hypothesis related to the fixed assets, we can see that there is a positive effect on the net profit margin at $1 \%$ significant level and no statistical significant effect on the return on assets. Therefore, we can reject the fourth hypothesis for the net profit margin and conclude that there is a statistical significant relationship between the fixed assets and profitability of industrial firms in Oman.

The results for the financial leverage variable show a negative and statistical significant effect on both net profit margin and return on assets. Therefore, we reject the fifth hypothesis and conclude that there is a statistical significant relationship between the financial leverage and profitability of industrial firms in Oman.

Finally, the results listed in Table 5 reveal a positive and statistical significant effect of current ratio on also both the net profit margin and the return on assets. Therefore, we can reject the sixth hypothesis and conclude that there is a statistical significant relationship between the working capital variable and profitability of industrial firms in Oman.

Table 5. Results of the panel ordinary least squares

\begin{tabular}{lllll}
\hline Dependent variable (PM) & & & \multicolumn{2}{c}{ Dependent variable (ROA) } \\
Variable & Coefficient & Prob. & Coefficient & Prob. \\
\hline TAXRATE & -0.085838 & 0.4787 & -0.020671 & 0.7554 \\
SIZE & 0.012997 & 0.0010 & 0.006996 & 0.0012 \\
GROWTH & 0.099845 & 0.0271 & 0.047482 & 0.0546 \\
FIXEDASSET & 0.305245 & 0.0000 & 0.016482 & 0.5215 \\
LMVE & -0.038793 & 0.0037 & -0.020817 & 0.0045 \\
CR & 0.020074 & 0.0000 & 0.009118 & 0.0003 \\
C & -0.338053 & 0.0001 & -0.083217 & 0.0727 \\
R-squared & 0.460592 & & 0.243605 & \\
Adjusted R-squared & 0.432203 & & 0.203794 & \\
S.E. of regression & 0.098832 & & 0.054173 & \\
Sum squared resid. & 1.113530 & & 0.334551 & \\
Log likelihood & 111.9479 & & 184.6991 & \\
F-statistic & 16.22383 & & 6.119136 & \\
Prob. (F-statistic) & 0.000000 & & 0.000014 & \\
Mean dependent var. & 0.149809 & & 0.099541 & \\
S.D. dependent var. & 0.131160 & & 0.060711 & \\
Akaike info criterion & -1.734676 & & -2.937176 & \\
Schwarz criterion & -1.572936 & -2.775436 & \\
Hannan-Quinn criter. & -1.668987 & -2.871487 & \\
Durbin-Watson stat. & 1.039376 & & 0.985314 & \\
\hline
\end{tabular}

\section{Conclusion}

This study examines the determinants of profitability of industrial firms listed on Muscat securities market. A panel ordinary least squares technique is utilized on a sample of 17 industrial companies covering the period 2006 till 2013. The results show a significant positive relationship between size, growth, fixed assets, working capital and profitability. In contrast, the average tax rate variable found to have a negative and insignificant relationship with profitability. The financial leverage variable provided evidence of a negative and significant 
relationship with profitability. The findings of this study are similar to the results of some variables utilized by Bhayani (2010), Nunes, Serrasqueiro, and Sequeira (2009), Asimakopoulos, Samitas, and Papadogonas (2009), Charumathi (2012), Boadi, Antwi, and Lartey (2013), Agiomirgianakis, Magoutas, and Sfakianakis (2013), Yazdanfar, (2013), Pratheepan (2014), Zaid, Ibrahim, and Zulqernain (2014). The study concludes that large growing companies that manage their working capitals efficiently command higher profits. On the other hand, increasing risk by using more debt will increase the required rate of returns and could negatively impact profit.

\section{References}

Agiomirgianakis, G. M., Magoutas, A. I., \& Sfakianakis, G. (2013). Determinants of profitability in the Greek tourism sector revisited: The impact of the economic crisis. Journal of Tourism and Hospitality Management, 1(1), 12-17.

Alipour, M. (2011). Working capital management and corporate profitability: Evidence from Iran. World Applied Sciences Journal, 12(7), 1093-1099.

Al-Jafari, M. K., \& Alchami, M. (2014). Determinants of bank profitability: Evidence from Syria. Journal of Applied Finance \& Banking, 4(1), 17-45.

Amir Shah, S. M., \& Sana, A. (2006). Impact of working capital management on the profitability of oil and gas sector of Pakistan. European Journal of Scientific Research, 15(3), 301-307.

Asimakopoulos, I., Samitas, A., \& Papadogonas, T. (2009). Firm specific and economy wide determinants of firm profitability: Greek evidence using panel data. Managerial Finance, 35(11), 930-939. http://dx.doi.org/10.1108/03074350910993818

Bain, J. S. (1951). Relation of profit rate to industry concentration: American manufacturing, 1936-1940. The Quarterly Journal of Economics, 65(3), 293-324. http://dx.doi.org/10.2307/1882217

Bashar, S. M., \& Islam, Md. I. (2014). Determinants of profitability in the pharmaceutical industry of Bangladesh. Journal of SUB, 5(1), 56-76.

Bennenbroek, N., \& Harris, R. I. D. (1995). An investigation of the determinants of profitability in New Zeal and manufacturing industries in 1986-87. Applied Economics, 27(11), 1093-1101.

Bhayani, S. J. (2010). Determinants of profitability in Indian cement industry: An economic analysis. South Asian Journal of Management, 17(4), 6-20.

Boadi, E. K., Antwi, S., \& Lartey, V. C. (2013). Determinants of profitability of insurance firms in Ghana. International Journal of Business and Social Research, 3(3), 43-50.

Burja, C. (2011). Factors influencing the company's profitability. Annales Universitatis Apulensis Series Oeconomica, 13(2), 215-224.

Charumathi, B. (2012). On the determinants of profitability of Indian life insurers: An empirical study. Proceedings of the World Congress on Engineering (Vol. 1). London, UK.

Chowdhury, A., \& Amin, Md. M. (2007). Working capital management practiced in pharmaceutical companies listed in Dhaka stock exchange. BRAC University Journal, 4(2), 75-86.

Dong, H. P., \& Su, J. (2010). The relationship between working capital management and profitability: A Vietnam case. International Research Journal of Finance and Economics, 49, 59-67.

Elsiefy, E. (2013). Determinants of profitability of commercial banks in Qatar: Comparative overview between domestic conventional and Islamic banks during the period 2006-2011. International Journal of Economics and Management Sciences, 2(11), 108-142.

Eriotis, N. P., Frangouli, Z., \& Ventoura-Neokosmides, Z. (2011). Profit margin and capital structure: An empirical relationship. The Journal of Applied Business Research, 18(2), 85-88.

Feeny, S. (2000). Determinants of profitability: An empirical investigation using Australian tax entities. The University of Melbourne. Melbourne Institute of Working Papers Series. Working Paper No.1/00, Melbourne.

Geroski, P. A., \& Jacquemin, A. (1988). The persistence of profits: A European comparison. The Economic Journal, 98(391), 375-389. http://dx.doi.org/10.2307/2233373

Goddard, J., Tavakoli, M., \& Wilson, J. O. S. (2005). Determinants of profitability in European manufacturing and services: Evidence from dynamic panel model. Applied Financial Economics, 15(18), 1269-1282. 
Grinyer, H. P., \& McKiernan, P. (1991). The determinants of corporate profitability in the UK electrical engineering industry. British Journal of Management, 2(1), 17-32. http://dx.doi.org/10.1111/j.1467-8551.1991.tb00012.x

Ha-Brookshire, J. (2009). Does the firm size matter on firm entrepreneurship and performance? Journal of Small Business and Enterprise Development, 16(1), 132-146. http://dx.doi.org/10.1108/FF14626000910932926

Hall, M., \& Weiss, L. W. (1967). Firm size and profitability. The Review of Economics and Statistics, 49(3), 319-331. http://dx.doi.org/10.2307/1926642

Hurdle, G. J. (1974). Leverage risk, market structure and profitability. The Review of Economics and Statistics, 56(4), 478-485. http://dx.doi.org/10.2307/1924463

Innocent, E. C., Mary, O. I., \& Matthew, O. M. (2013). Financial ratio analysis as a determinant of profitability in Nigerian pharmaceutical industry. International Journal of Business and Management, 8(8), 107-117.

Ito, K., \& Fukao, K. (2010). Determinants of the profitability of Japanese manufacturing affiliates in China and other regions: Does localization of procurement, sales and management matter? The World Economy, 33(12), 1639-1671. http://dx.doi.org/10.1111/j.1467-9701.2009.01236.x

Keith, G. (1998). Determinants of growth and profitability in small entrepreneurial firms. International Journal of Entrepreneurial Behavior \& Research, 4(1), 18-27.

Malik, H. (2011). Determinants of Insurance Companies Profitability: An analysis of insurance sector of Pakistan. Academic Research International, 1(3), 315-321.

McDonald, J. T. (1999). The determinants of firm profitability in Australian manufacturing. The Economic Record, 75(229), 115-126.

Menard, S. (1995). Applied logistic regression analysis. Sage University paper series on quantitative applications in the social sciences, 07-106. Thousand Oaks, CA: Sage.

Mistry, D. S. (2012). Determinants of profitability in Indian automotive industry. Tecnia Journal of Management Studies, 7(1), 20-23.

Muscat Securities Market. (2015). Retrieved from http://www.msm.gov.om

Myers, R. (1990). Classical and modern regression with applications (2nd ed.). Boston, MA: Duxbury.

Nunes, P. J. M., Serrasqueiro, Z. M., \& Sequeira, T. N. (2009). Profitability in Portuguese service industries: A panel data approach. The Service Industries Journal, 29(5), 693-707. http://dx.doi.org/10.1080/02642060902720188

Pratheepan, T. (2014). A Panel data analysis of profitability determinants: Empirical results from Sri Lankan manufacturing companies. International Journal of Economics, Commerce and Management, 2(12), 1-9.

Stierwald, A. (2010). Determinants of profitability: An analysis of large Australian firms. The University of Melbourne. Melbourne Institute Working Papers Series. Working Paper No.3/10, Melbourne. http://dx.doi.org/10.2139/ssrn.1632749

Yazdanfar, D. (2013). Profitability determinants among micro firms: Evidence from Swedish data. International Journal of Managerial Finance, 9(2), 151-160. http://dx.doi.org/10.1108/17439131311307565

Zaid, N. A. M., Ibrahim, W. M. F. W., \& Zulqernain, N. S. (2014). The Determinants of profitability: Evidence from Malaysian construction companies. Proceedings of 5th Asia-Pacific Business Research Conference. Kuala Lumpur, Malaysia.

\section{Copyrights}

Copyright for this article is retained by the author(s), with first publication rights granted to the journal.

This is an open-access article distributed under the terms and conditions of the Creative Commons Attribution license (http://creativecommons.org/licenses/by/3.0/). 